Research Institute for the Biology of Farm Animals, Dummerstorf', Germany and The University of Lethbridge, Department of Chemistry and Biochemistry, Lethbridge, Alberta, Canada²

CHANGPING XIE', ELKE ALBRECHT', JOCHEN WEGNER', GUDRUN A. BROCKMANN', CHRISTOPHER KAZALA ${ }^{2}$, RANDALL J. WESELAKE ${ }^{2}$ and KLAUS ENDER'

\title{
Leptin, a palatability molecule ? - A Review
}

\begin{abstract}
Summary
Leptin is a hormone involved in the regulation of feed intake and energy balance in animals. The expression and secretion of leptin is highly correlated with body fat mass and adipocyte size. The regulation of leptin is integrated into a broad regulatory network including other hormones and cytokines. Leptin's effects on food intake and energy expenditure is thought to be mediated centrally via various neurotransmitters. Peripheral hormones, including insulin and glucocorticoids, stimulate the expression of leptin. While leptin action has been well studied in rodents and humans, its role in farm animals remains to be determined in relation to feed intake and energy metabolism. Leptin may play a role in the regulation of regional fat distribution. The deposition of intramuscular fat (marbling) is positively correlated with the palatability of beef and, therefore, investigations into the mechanisms underlying fat accretion in this depot are underway. Studying the relationship between leptin and lipid metabolizing enzymes may provide us with clues on the mechanisms governing site-specific fat accretion in farm animals.
\end{abstract}

Key words: leptin, adipocytes, fat distribution, marbling

\section{Zusammenfassung}

Titel der Arbeit: Leptin, ein Molekül für die Schmackhaftigkeit? - Ein Überblick

Leptin ist ein Hormon, das die Futteraufnahme und die Energiebilanz der Tiere reguliert. Die Expression und Sekretion von Leptin ist mit der Körperfettmasse und der Fettzellgröße hoch korreliert. Die Regulation von Leptin ist in einem umfangreichen regulatorischem Netzwerk, begleitet von verschiedenen Hormonen und $\mathrm{Zy}$ tokinen, integriert. Es wird angenommen, daß die Auswirkung von Leptin auf Futteraufnahme und Energieverbrauch zentral durch Neurotransmitter vermittelt wird. Periphere Hormone, wie Insulin und Glucocorticoid können die Expression von Leptin dramatisch stimulieren. Während Leptin bei Labornagern und Mensch umfangreich untersucht wurde, besteht bezüglich Futteraufnahme und Energiestoffwechsel bei landwirtschaftlichen Nutztieren noch erheblicher Forschungsbedarf. Es ist denkbar, daß Leptin auch als Regulator für die regionale Fettverteilung wirksam ist und somit zunehmend Beachtung in der Fleischqualitätsforschung erfährt. Die Einlagerung von intramuskulärem Fett (Marmorierung) ist eng mit dem Geschmack des Fleisches verbunden. Das Zusammenspiel von Leptin mit Enzymen wird unter dem Aspekt der regionalen Fettverteilung zusammenge$\mathrm{faBt}$.

Schlüsselwörtex: Leptin, Fettzellen, Fettverteilung, Marmorierung

\section{Introduction}

The major goals of meat animal science are to achieve higher lean protein production and improve productive efficiency while retaining or increasing favourable aspects of meat quality. Production-oriented animal management aims to maximize meat production while reducing the deposition of unfavourable fat, while quality-oriented strategies focus on increasing the amount of intramuscular fat to achieve better meat 
quality. Both approaches require adequate knowledge about the mechanisms controlling the deposition and partitioning of fat tissue.

A detailed knowledge of the mechanism of fat tissue development is crucial to the treatment of obesity in humans and manipulation of meat production in livestock. In vitro studies have suggested that many factors are involved in adipocyte proliferation and differentiation, including adipogenic gene products (e.g. adipocyte lipid binding protein-2, glucose transport protein-4 and fatty acid synthase) and transcription factors (e.g. CAAT/enhancer binding proteins alpha and beta, and peroxisome proliferatoractivated receptor gamma). Since the murine leptin gene was cloned in 1994 (ZHANG et al., 1994), the protein hormone has been studied extensively due to its unique role in food intake and energy balance, and potential therapeutic value. The general biological role of leptin has been reviewed thoroughly e.g. by HOUSEKNECHT et al. (1998) and FRIEDMAN and HALAAS (1998). The following summarizes some of the major features of leptin action and its regulation, with attention drawn to its possible role in the accumulation and distribution of fat in farm animals.

\section{Leptin and the leptin receptor}

In an attempt to explain the regulation of energy balance, the lipostatic theory proposed that a product of fat metabolism circulated in the blood and interacted with receptors associated with the central nervous system (KENNEDY, 1953). A parabiosis experiment performed by HERVY (1958) provided evidence for the existence of this circulating factor. It was not until 1994, however, that this factor was first characterized and its gene cloned by Friedman's group (ZHANG et al., 1994). The leptin gene was isolated through positional cloning from ob/ob mice that failed to produce leptin and displayed extreme obesity and hyperphagia. The protein hormone has been shown to be initially translated into a 167 amino acid precursor, from which a 21 amino acid signal peptide is cleaved. Mature leptin is a $16 \mathrm{kDa}$ non-glycosylated polypeptide with two cysteines forming an intramolecular disulfide bond (ZHANG et al., 1994). There is high degree of homology in leptin from different species.

Leptin may function as part of a signalling pathway from adipose tissue that acts to regulate feed intake and energy stores (ZHANG et al., 1994). Obesity in both rodents and humans is generally associated with elevated leptin levels (CARO et al., 1996). Furthermore, obesity is a quantitative trait for which a series of genes are responsible (CHAGNON et al., 1997). Leptin is produced in and secreted abundantly from adipose tissue, and at lower levels in placenta and gastric epithelium, suggesting a role for leptin in both energy balance and reproduction (BADO et al., 1998; MASUZAKI et al., 1997). Leptin may also participate in hematopoiesis (BENNETT et al., 1996). Another form of mouse obesity, designated $\mathrm{db} / \mathrm{db}$, demonstrates symptoms similar to those observed in ob/ob mice, but the $\mathrm{db} / \mathrm{db}$ mice failed to be rescued by leptin administration (TARTAGLIA et al., 1995). It was proposed that $\mathrm{db} / \mathrm{db}$ mice might have a mutation of the gene encoding the leptin receptor. In 1995, Tartaglia and coworkers reported the cloning of the mouse leptin receptor and mapped it to chromosome 4 (TARTAGLIA et al., 1995). 
The genes for both leptin and the leptin receptor have been cloned and sequenced from the mouse, rat and human, as well as from bovine, porcine and ovine tissues (ZHANG et al., 1994; OGAWA et al., 1996; MASUZAKI et al., 1995; LIEN et al., 1997; RAMSAY et al., 1998; DYER et al., 1997). The murine leptin receptor is a 1142 amino acid transmembrane protein. The receptor has been suggested to be a glycoprotein 130 analog, with the extracellular region containing a Trp-Ser-X-Trp-Ser motif and the intracellular region containing both Janus kinase and Stat interaction sequences (WHITE et al., 1996). This implicated the signal transduction mechanism of the leptin receptor as a member of the class I cytokine receptor family, acting either via the Jak-Stat signal transduction pathway, or through the MAPK or PI-3 systems (WATOWICH et al., 1996).

The gene encoding the leptin receptor in $\mathrm{db} / \mathrm{db}$ mice has been shown to undergo abnormal splicing, yielding a truncated receptor. At least six leptin receptor isoforms have been found in mice. These isoforms are translated from differently spliced leptin receptor mRNA precursors (WANG et al., 1996). In db/db mice, the truncated leptin receptor failed to process the ligand signal (LEE et al., 1996). In obese Zucker rats, a point mutation in the extracellular domain (resulting in a Gln to Pro conversion) has been suggested to impair receptor dimerization, thereby blocking the signal transduction pathway.

Leptin receptors are found in many tissues including choroid plexus, hypothalamus, lung, and pancreatic cells. The long form receptor, however, has been shown to be prevalent in the hypothalamus region, while the short form receptors were more dispersed. The biological function of the short form leptin receptor remains unclear.

\section{Role of leptin in energy balance}

Leptin was hypothesized to be a "satiety factor" because its absence in ob/ob mice results in extreme obesity and hyperphagia. After treatment with leptin, ob/ob mice reduce food intake and, ultimately, their body weight (PELLEYMOUNTER et al., 1995). As well, leptin treatment has been shown to result in the elimination of all visible fat in normal rodents (CHEN et al., 1996). Leptin had been considered to be a promising candidate in therapeutic approaches to the treatment of human obesity because leptin-induced reductions in both body weight and fat deposition were retained for several weeks after the termination of leptin administration (CHEN et al., 1996). Subsequent studies, however, indicated that its effects must be more complex than simple appetite suppression. When injected with leptin, lean mice lost considerable body weight, yet their appetite was essentially unchanged (LEVIN et al., 1996). It required 5 to 10 times more leptin to reduce the fat stores of diet-induced obese mice than to weight-matched ob/ob mice. The action of leptin appears to be more complicated. In most human obesity cases (CONSIDINE et al., 1996), as well as in model animals e.g. mice, (TIMTCHENKO et al., 1999), obese individuals displayed elevated plasma leptin levels compared to subjects of normal weight, thus demonstrating "leptin resistance". It was observed that the level of leptin expression might simply be an indicator of adipocyte size in both lean and obese mice 
(HOUSEKNECHT et al., 1996). Leptin levels demonstrate circadian rhythm (SINHA et al., 1996) therefore the amount of leptin in the body is not at constant level but pulsatile (LICINIO et al., 1997). Nevertheless, the level of leptin expression might be considered an indicator of fat accumulation provided that the physiological fluctuation of expression is also addressed.

\section{Mechanism of leptin function}

Although many facets of leptin action are not well understood, it is clear that leptin can suppress feed intake and that it can lead to body weight reduction. Neuropeptide $\mathrm{Y}$ has been shown to be a potent stimulator of feed intake and inhibitor of brown fat thermogenesis and, subsequently, its action has been incorporated into our understanding of the leptin signal pathway. Increased leptin levels, due to abundant fat stores, have been shown to decrease Neuropeptide Y expression (SCHWARTZ et al., 1996). This, in turn, activated the sympathetic nervous system and stimulated the heat producing activity of brown adipose tissue resulting in increased whole body energy expenditure and weight loss. While this theory is attractive, it has recently been reported that Neuropeptide Y-deficient mice are normal with respect to food intake. Thus, it is likely that alternative factors exist which can replace the Neuropeptide Ydependent pathway. In addition, humans, in contrast to rodents, have very small brown adipose tissue deposits, but it is not clear what role these deposits may play in thermally-based weight loss.

An alternative theory concerning the role of leptin suggests that its importance in feed intake may be linked to its ability to regulate the neuroendocrine system during periods of starvation. In this regard, the interaction between leptin and type 2 corticotropinreleasing hormone receptor in the ventromedial hypothalamus (MAKINO et al., 1998) has been addressed. Data have suggested that weight reduction and decreased food intake after administration of a high dose of corticosterone depend, at least partially, on leptin secretion. Obviously more research on all metabolic aspects of leptin is necessary.

There is expanding evidence that suggests leptin may act peripherally. Leptin receptors are found outside the central nervous system, but only the short forms of the leptin receptor prevail in most tissues. Leptin treatment of hepatic cells has been shown to inhibit several insulin-induced activities, including tyrosine phosphorylation of the insulin receptor substrate-1 and down-regulation of gluconeogenesis (COHEN et al., 1996).

\section{Regulation of leptin expression}

The amount of leptin in plasma can be regulated via gene transcription and/or protein turnover. For example, CCAAT/enhancer binding proteins alpha and beta, and peroxisome proliferator-activated receptor gamma have been implicated in the transcriptional regulation of leptin (HE et al., 1995; HWANG et al., 1996; MILLER et al., 1996; KALLEN and LAZAR, 1996; MASON et al., 1998). Other factors shown to 
regulate the expression of leptin include glucocorticoids, insulin, cAMP and betaadrenergic receptors. Influences of age, sex, diet and fasting on leptin expression have also been investigated (SLIEKER et al., 1996; DE VOS et al 1997).

Factors reported to induce leptin secretion include insulin and inflammatory mediators such as lipopolysaccharide, interleukin-1beta and tumor necrosis factor-alpha (KIRCHGESSSNER et al., 1997). Insulin has been shown to act on both leptin transcription and regulation of its secretion. Furthermore, insulin and leptin appear to be part of a feedback loop wherein insulin stimulates leptin secretion and circulating leptin inhibits insulin production (independently of feeding). Although speculative, there is evidence to suggest that adipocyte size may be a major determinant of leptin mRNA expression (COLLINS et al., 1996). Perhaps insulin and the size of white adipocytes (reflecting stored fat amount), determine the actual quantity of leptin released.

\section{Leptin and meat science}

Ongoing research in meat science is attempting to achieve a balance between production efficiency and product palatability. One of the main goals in animal production is to increase the quantity of intramuscular fat while at the same time reducing the quantity of fat in other depots. Through classical selection schemes, animal breeds differing in fat deposition have already been established. These animals could be useful in studying the effects of genetic contribution to meat production and fat regulation.

It is of particular interest to study fat distribution mechanisms with regard to both clinical relevance in humans and meat quality in animals. In humans, the subcutaneous fat depot is considered to be of less risk than abdominal fat with regard to obesityrelated pathological consequences among similarly overweight subjects (BOUCHARD et al., 1993). Leptin seems to be one of the factors involved in depot-specific fat distribution. In humans, leptin has been shown to be expressed at significantly higher levels in subcutaneous tissue than in omental tissue (MONTAGUE et al., 1997). Higher expression has also been observed in swine subcutaneous fat tissue than in the omental and retroperitoneal fat depots (WERNER et al., 1998). In our studies of the bovine system, the highest levels of leptin mRNA expression were found in perirenal adipose tissue, followed by subcutaneous adipose tissue with the lowest levels seen in mesenteric adipose tissue (our unpublished data). As indicated in obesity studies, differences in regional fat distribution are even more complex in terms of genetic and physiological determinants when compared to the previously mentioned observations concerning leptin levels in obese individuals. Factors that may be involved in modulating fat distribution include age, gender, and various regulators controlling the development of adipose cells (REBUFFE-SCRIVE et al., 1985). Significant association had been shown between variation of lipoprotein lipase activity in adipose tissue and regional fat distribution, lipoprotein lipase therefore had been proposed to be a key regulator of regional fat distribution in various adipose areas. The lipoprotein lipase activity as well as the amount of lipoprotein lipase mRNA were found to be 
higher in abdominal fat tissue than in gluteal fat in men, while the opposite was observed in women (FRIED and KRAL, 1987; RAISON et al., 1988). Similar to leptin expression levels, variation in lipoprotein lipase activity has been shown to be affected by differences in adipocyte size (FRIED and KRAL, 1987). This observation suggested the existence of a possible common regulatory mechanism involving leptin and lipoprotein lipase. The analysis in the bovine system indicated that the lowest amount of bovine lipoprotein lipase mRNA was found in the perirenal fat tissue, while the highest levels were observed in mesenteric fat (our unpublished data). Despite these observations, direct evidence of the relationship between leptin and lipoprotein lipase, as well as other members in the adipogenic regulatory pathway, remains to be elucidated.

\section{Conclusion}

Though body energy gain may vary under different physiological conditions, variation in response to many external factors is undoubtedly influenced by genotype. QTL analysis in segregating pedigree structures and candidate gene strategies are now emerging as complementary tools in the search for genes responsible for meat quality traits such as adipose tissue development and fat distribution in animals. Among numerous regulatory and metabolic molecules, leptin is a particularly prominent candidate with respect to further studies of feed intake, gender related fat accumulation and regional fat distribution in farm animals. Different leptin levels and gene transcript amounts may serve as potential selection markers for breeding programs towards improving meat quality. The analysis of the relationships between leptin and other fatrelated metabolic factors will help to understand the role of leptin in fat deposition and perhaps ultimately in meat quality.

\section{References}

BADO, A.; LEVASSEUR, S.; ATTOUB, S.; KERMORGANT, S.; LAIGNEAU, J.P.; BORTOLUZZI, M.N.; MOIZO, L.; LEHY, T.; GUERRE-MILLO, M.; LE MARCHAND-BRUSTEL, Y.; LEWIN, M.J.: The stomach is a source of leptin. Nature, London 394 (1998), 790-793

BENNETT, B.D.; SOLAR, G.P.; YUAN, J.Q.; MATHIAS, J.; THOMAS, G.R., MATTHEWS, W.: A role for leptin and its cognate receptor in hematopoiesis. Curr Biol 6 (1996), 1170-1180

BOUCHARD, C.; DESPRES, J.-P.; MAURIEGE, P.: Genetic and nongenetic determinants of regional fat distribution. Endocrine Rev. 14 (1993), 72-92

CARO, J.F.; KOLACZYNSKI, J.W.; NYCE, M.R.; OHANNESIAN, J.P.; OPENTANOVA, I.; GOLDMAN, W.H.; LYNN, R.B.; ZHANG, P.L.; SINHA, M.K.; CONSIDINE, R.V.: Decreased cerebrospinal-fluid/serum leptin ratio in obesity: a possible mechanism for leptin resistance. Lancet 348 (1996), 159-161

CHAGNON, Y.C.; PERUSSE, L.; BOUCHARD, C.:

Familial aggregation of obesity, candidate genes and quantitative trait loci. Curr Opin Lipidol 8 (1997), 205- 211

CHEN, G.; KOYAMA, K.; YUAN, X.; LEE, Y.; ZHOU, Y.T.; O'DOHERTY, R.; NEWGARD, C.B.; UNGER, R.H.:

Disappearance of body fat in normal rats induced by adenovirus-mediated leptin gene therapy. Proc. Natl. Acad. Sci. U S A 93 (1996), 14795-14799

COHEN, B.; NOVICK, D.; RUBINSTEIN, M.:

Modulation of insulin activities by leptin [see comments]. Science, Washington 274 (1996), 1185-1188 
COLLINS, S.; KUHN, C.M.; PETRO, A.E.; SWICK, A.G.; CHRUNYK, B.A.; SURWIT, R.S.:

Role of leptin in fat regulation. Nature, London 380 (1996), 677

CONSIDINE, R.V.; SINHA, M.K.; HEIMAN, M.L.; KRIAUCIUNAS, A.; STEPHENS, T.W.; NYCE, M.R.;

OHANNESIAN, J.P.; MARCO, C.C.; MCKEE, L.J.; BAUER, T.L.:

Serum immunoreactive-leptin concentrations in normal-weight and obese humans. N. Engl. J. Med. 334 (1996), 292-295

DE VOS, R.; GUISEZ, Y.; VAN DER HEYDEN, J.; WHITE, D.W.; KALAI, M.; FOUNTOULAKIS, M.; PLAETINCK, G.:

Ligand-independent dimerization of the extracellular domain of the leptin receptor and determination of the stoichiometry of leptin binding. J. Biol. Chem. 272 (1997), 18304-18310

DYER, C.J.; SIMMONS, J.M.; MATTERI, R.L.; KEISLER, D.H.:

cDNA cloning and tissue-specific gene expression of ovine leptin, NPY- Y1 receptor, and NPY-Y2 receptor. Domest. Anim. Endocrino. 114 (1997), 295-303

FRIED, S.; KRAL, J.G.:

Sex differences in regional distribution of fat cell size and lipoprotein lipase activity in morbidly obese patients. Int. J. Obes. 11 (1987), 129-140

FRIEDMAN, J. M.; HALAAS, J. L.:

Leptin and the regulation of body weight in mammals. Nature, London 395 (1998), 763-770

HE, Y.; CHEN, H.; QUON, M.J.; REITMAN, M.:

The mouse obese gene. Genomic organization, promoter activity, and activation by CCAAT/enhancerbinding protein alpha. J Biol Chem 270 (1995), 28887-28891

HERVY, G.R.:

The effects of lesions in the hypothalamus in parabiotic rats. J. Physiol. 145 (1958), 336-352

HOUSEKNECHT, K.L.; MANTZOROS, C.S.; KULIAWAT, R.; HADRO, E.; FLIER, J.S.; KAHN, B.B.:

Evidence for leptin binding to proteins in serum of rodents and humans: modulation with obesity. Diabetes 45 (1996), 1638-1643

HOUSEKNECHT, K.L.; BAILE, C.A.; MATTERI, R.L.; SPURLOCK, M.E.: The biology of leptin: A Review. J. Anim. Sci., Albany, N.Y. 76 (1998), 1405-1420

HWANG, C.; MANDRUP, S.; MACDOUGALD, O.A.; GEIMAN, D.E.; LANE, M.D.:

Transcriptional activation of the mouse obese $(\mathrm{Ob})$ gene by CCAAT/enhancer binding protein alpha. Proc. Natl. Acad. Sci. 93 (1996), 873-877

KALLEN, C.B.; LAZAR, M.A.:

Antidiabetic thiazolidinediones inhibit leptin (ob) gene expression in 3T3-L1 adipocytes. Proc. Natl. Acad. Sci. 93 (1996), 5793-5796

KENNEDY, G.C.:

The role of depot fat in the hypothalamic control of food intake in the rat. Proc. R. Soc. 140 (1953), 578-592

KIRCHGESSNER, T.G.; UYSAL, K.T.; WIESBROCK, S.M.; MARINO, M.W.; HOTAMISLIGIL, G.S.:

Tumor necrosis factor-alpha contributes to obesity-related hyperleptinemia by regulating leptin release from adipocytes. J Clin Invest. 100 (1997), 2777-2782

LEE, G.H.; PROENCA, R.; MONTEZ, J.M.; CARROLL, K.M.; DARVISHZADEH, J.G.; LEE, J.I.; FRIEDMAN, J.M.: Abnormal splicing of the leptin receptor in diabetic mice. Nature, London 379 (1996), 632-635

LEVIN, N.; NELSON, C.; GURNEY, A.; VANDLEN, R.; DE SAUVAGE, F.: Decreased food intake does not completely account for adiposity reduction after ob protein infusion. Proc. Natl. Acad. Sci. 93 (1996), 1726-1730

LICINIO, J.; MANTZOROS, C.; NEGRAO, A.B.; CIZZA, G.; WONG, M.L.; BONGIORNO, P.B.; CHROUSOS, G.P.; KARP, B.; ALLEN, C.; FLIER, J.S.; GOLD, P.W.: Human leptin levels are pulsatile and inversely related to pituitary-adrenal function. Nat. Med. 3 (1997), 575-579

LIEN, S.; SUNDVOLD, H.; KLUNGLAND, H.; VAEGE, D. I.:

Two novel polymorphisms in the bovine obesity gene (OBS). Anim. Genet. 28 (1997), 245-245

MAKINO, S.; NISHIYAMA, M.; ASABA, K.; GOLD, P.W.; HASHIMOTO, K.: Altered expression of type 2 CRH receptor mRNA in the VMH by glucocorticoids and starvation. Am. J. Physiol. 275 (1998), R1138-R1145 
MASON, M.M.; HE, Y.; CHEN, H.; QUON, M.J.; REITMAN, M.:

Regulation of leptin promoter function by Sp1, C/EBP, and a novel factor. Endocrinology 139 (1998), 1013-1022

MASUZAKI, H.; OGAWA, Y.; SAGAWA, N.; HOSODA, K.; MATSUMOTO, T.; MISE, H.; NISHIMURA, H.; YOSHIMASA, Y.; TANAKA, I.; MORI, T.; NAKAO, K.:

Nonadipose tissue production of leptin: leptin as a novel placenta- derived hormone in humans. Nat Med 3 (1997), 1029-1033

MASUZAKI, H.; OGAWA, Y.; ISSE, N.; SATOH, N.; OKAZAKI, T.; SHIGEMOTO, M.; MORI, K.; TAMURA, N.; HOSODA, K.; YOSHIMASA,Y.; JINGAMI, H.; KAWADA, T.; NAKAO, K.:

Human obese gene expression. Adipocyte-specific expression and regional differences in the adipose tissue. Diabetes 44 (1995), 855-858

MILLER, S.G.; DE VOS, P.; GUERRE-MILLO, M.; WONG, K.; HERMANN, T.; STAELS, B.; BRIGGS, M.R., AUWERX, J.:

The adipocyte specific transcription factor C/EBPalpha modulates human ob gene expression. Proc. Natl. Acad. Sci. U S A 93 (1996), 5507-5511

MONTAGUE, C.T.; PRINS, J.B.; SANDERS, L.; DIGBY, J.E.; O'RAHILLY, S.:

Depot- and sex-specific differences in human leptin mRNA expression: implications for the control of regional fat distribution. Diabetes 46 (1997), 342-347

OGAWA, Y.; ISSE, N.; OKAZAKI, T.; SATOH, N.; MASUZAKI, H.; MORI, K.; TAMURA, N.; HOSODA, K.; NAKAO, K.:

Molecular cloning of rat leptin receptor isoform complementary DNAs-- identification of a missense mutation in Zucker fatty (fa/fa) rats. Biochem. Biophys. Res. Commun. 225 (1996), 75-83

PELLEYMOUNTER, M.A.; CULLEN, M.J.; BAKER, M.B.; HECHT, R.; WINTERS, D.; BOONE, T.; COLLINS, F.:

Effects of the obese gene product on body weight regulation in ob/ob mice. Science, Washington 269 (1995), 540-543

RAISON, J.; BASDEVANT, A.; SITT, A.; GUY-GRAND, B.:

Regional differences in adipose tissue lipoprotein lipase activity in relation to body fat distribution and menopausal status in obese women. Int. J. Obes. 12 (1988), 465-472

RAMSAY, T.G.; YAN, X.; MORRISON C.:

The obesity gene in swine: sequence and expression of porcine leptin. J. Anim. Sci., Albany, N.Y. 76 (1998), 484-490

REBUFFE-SCRIVE M, ENK L, CRONA N, LOENNROTH P, ABRAHAMSSON L, SMITH U, BJOERNTORP P :

Fat cell metabolism in different region in women. Effects of menstrual cycle, pregnancy and lactation. J. Clin. Invest. 75 (1985) 1973-1976

SCHWARTZ, M.W.; BASKIN, D.G.; BUKOWSKI, T.R.; KUIJPER, J.L.; FOSTER, D.; LASSER, G.; PRUNKARD, D.E.; PORTE, D., JR.; WOODS, S.C.; SEELEY, R.J.; WEIGLE, D.S.:

Specificity of leptin action on elevated blood glucose levels and hypothalamic neuropeptide Y gene expression in ob/ob mice. Diabetes 45 (1996), 531-535

SINHA, M.K.; OHANNESIAN, J.P.; HEIMAN, M.L.; KRIAUCIUNAS, A.; STEPHENS, T.W.; MAGOSIN, S.; MARCO, C.; CARO, J.F.:

Nocturnal rise of leptin in lean, obese, and non-insulin-dependent diabetes mellitus subjects. J. Clin. Invest. 97 (1996), 1344-1347

SLIEKER, L.J.; SLOOP, K.W.; SURFACE, P.L.; KRIAUCIUNAS, A.; LAQUIER, F.; MANETTA, J.; BUE-

VALLESKEY, J.; STEPHENS, T.W.: Regulation of expression of ob mRNA and protein by glucocorticoids and cAMP. J. Biol. Chem. 271 (1996), 5301-5304

TARTAGLIA, L.A.; DEMBSKI, M.; WENG, X.; DENG, N.; CULPEPPER, J.; DEVOS, R.; RICHARDS, G.J.; CAMPFIELD, L.A.; CLARK, F.T.; DEEDS, J.:

Identification and expression cloning of a leptin receptor, OB-R. Cell 83 (1995), 1263-1271

TIMTCHENKO, D.; KRATZSCH, J.; SAUERWEIN, H.; WEGNER, J.; SOUFFRANT, W. B.; SCHWERIN, M.; BROCKMANN, G. A.:

Gene expression and fat storage in growth-selected mice. Int. J. Obesity (1999) in press

WANG, M.Y.; ZHOU, Y.T.; NEWGARD, C.B.; UNGER, R.H.:

A novel leptin receptor isoform in rat. FEBS Lett 392 (1996), 87-90 
WATOWICH, S.S.; WU, H.; SOCOLOVSKY, U.; KLINGMULLER, S.; CONSTANTINESCU, S.N.; LODISH, H.F.:

Cytokine receptor signal transduction and the control of hematopoietic cell development. Annu. Rev. Cell Dev. Biol. 12 (1996), 91-128

WERNER, P.; NEUENSCHWANDER, S.; EICHINGER, H.M.; FRIES, R.; STRANZINGER, G.: Comparison of leptin mRNA levels in different adipose tissues from pig. The $26^{\text {th }}$ International Conference on Animal Genetics, Auckland. Aug., 9-14, 1998

WHITE, D.W.; TARTAGLIA, L.A.:

Leptin and OB-R: body weight regulation by a cytokine receptor. Cytokine Growth Factor Rev. 7 (1996), 303-309

ZHANG, Y.; PROENCA, R.; MAFFEI, M.; BARONE, M.; LEOPOLD, L.; FRIEDMAN J.M.:

Positional cloning of the mouse obese gene and its human homologue. Nature, London 372 (1994), $425-432$

Received: 24.11 .1998

Accepted: 21.01 .1999

Author's addresses

M. Sc. CHANGPING XIE, Dr. ELKE ALBRECHT, Dr. JOCHEN WEGNER, Dr. GUDRUN A. BROCKMANN, Prof. Dr. habil. KLAUS ENDER

Research Institute for Biology of Farm Animals

Wilhelm-Stahl-Allee 2

D-18196 Dummerstorf

Germany

E-Mail: wegner@fbn-dummerstorf.de

M.Sc. CHRISTOPHER KAZALA, Prof. RANDALL J. WESELAKE

The University of Lethbridge, Department of Chemistry and Biochemistry

4401 University Drive

Lethbridge, Alberta

Canada T1K 3M4 


\section{Der Bundesverband für Tiergesundheit informiert! (Dossier 16, 1999)}

\section{Gentechnologie in der Tiergesundheit}

Die Anwendung der Gentechnologie für die Gesunderhaltung von Tieren steht noch am Anfang. Sie kann dazu beitragen, daß Impfstoffe wesentlich zielgerichteter vor Krankheiten schützen wie z.B.:

- Subunit-Impfstoffe: Mit ihnen wird es u.a. möglich, nur mit den Proteinen zu impfen, die für die Immunisicrung notwendig sind. Ohne den Ballast nicht relevanter Bestandteile können höhere Konzentrationen der immunogen wirkenden Anteile erzielt werden - und damit eine wesentlich bessere Wirksamkeit.

- Deletions-Impfstoffe: Bei diesen Impfstoffen werden bestimmte Genbestandteile aus dem Infektionserreger entfernt (deletiert). Dies kann zur Markierung des Impfstammes genutzt werden, der so von der krankheitsauslösenden Variante unterscheidbar wird, aber auch zur Abschwächung von Erregern mit hohem Infektionspotential. Bei einigen Indikationen wird es dadurch überhaupt erst möglich, Impfstoffe zu entwickeln, durch die ein Erkrankungsrisiko für das Tier ausgeschlossen werden kann.

- Vektor-Impfstoffe: Bei diesen Impfstoffen bekommt ein Trägervirus oder -bakterium die Genabschnitte für das immunisierende Protein anderer Krankheitserreger eingepflanzt. Vektor-Impfstoffe vereinen dadurch die Sicherheit von Impfstoffen mit abgetöteten Erregern und die gute Wirksamkeit konventioneller Lebendimpfstoffe, die vermehrungsfähige Keime enthalten. Zudem können Vektor-Impfstoffe als Mehrfachimpfstoffe gleichzeitig gegen mehrere Krankheiten wirken.

- Hidden Antigens: Verborgene Antigene, mit denen schon jetzt bei Parasitenvakzinen gearbeitet wird, lösen Antikörper-Reaktionen des Wirtstieres aus, die dann den Parasiten schädigen. Dadurch kann zum Beispiel die Fortpflanzungsfähigkeit des Parasiten deutlich beeinträchtigt werden.

Gentechnisch erzeugte Impfstoffe können heute bereits gegen virusbedingte Infektionskrankheiten schützen, so zum Beispiel gegen

- die Aujeszky'sche Krankheit, eine meist tödlich verlaufende Herpesviruserkrankung beim Schwein

- gegen Hühnerpocken und gleichzeitig gegen die atypische Geflügelpest

Auch gegen bakterielle Infektionen und Parasitenbefall sind gentechnisch hergestellte Impfstoffe im Einsatz: So erhielt eine Vakzine gegen Schweinediarrhöe durch E. coli-Bakterien als einer der ersten gentechnisch veränderten Impfstoffe bereits 1992 eine europäische Zulassung.

Subunit- und Deletions-Impfstoffe können als Markerimpfstoffe eingesetzt werden. Sie ermöglichen die sichere Unterscheidung von natürlich infizierten und geimpften Tieren. Diese Impfstoffe enthalten Erreger, z.B. Viren, deren Hülle gegenüber dem natürlich vorkommenden Erreger gezielt verändert worden ist. Dadurch bilden natürlich infizierte und geimpfte Tiere unterschiedliche Antikörper. Gekoppelt mit der entsprechenden Diagnostik, steht die wirkungsvolle Immunprophylaxe damit heute nicht mehr im Widerspruch zu handelspolitischen Erfordemissen: Mit markierten Impfstoffen kann sichergestellt werden, daß nur gesunde bzw. geimpfte Tiere vermarktet werden. Dadurch wird die effiziente Bekämpfung von Tierseuchen wie der Schweinepest möglich, ohne ganze Bestände in einer Region töten zu müssen.

Bei der Infektiösen Bovinen Rhinotracheitis (IBR), einer Erkrankung der Atemwege und der Geschlechtsorgane beim Rind, ermöglichen parallel zur Impfung mit Markerimpfstoffen laufende Überwachungsprogramme die Auslöschung der Seuche.

Die biochemische Diagnostik hat die geringere Selektivität und große Störanfälligkeit der herkömmlichen Diagnosemethoden verbessert. Sie beruht auf der Verwendung selektiv arbeitender Enzyme, die heute bereits zum Teil in hoher Ausbeute und großer Reinheit gentechnisch hergestellt werden.

Zunehmend ermöglichen monoklonale Antikörper- in Zellkulturen erzeugte Antikörper mit einer bestimmten Eigenschaft - die genauere Diagnose von Infektionen. Die Diagnostik mit Hilfe von Antikörpern bildet auch die Grundlage für die Kontrolle von Impfprogrammen mit Markerimpfstoffen.

Das wachsende Wissen um die Struktur des Erbgutes macht es heute möglich, Krankheitserreger direkt auf dieser Ebene nachzuweisen - zum Beispiel beim Nachweis von Viren. Eine zuverlässige Krankheits-Diagnose ist sehr schnell und mit geringem Probenmaterial bereits in einer sehr frühen Phase der Infektion möglich. Die dabei hauptsächlich eingesetzte Technik der Polymerase-Kettenreaktion wird bereits genutzt bei:

- Brucelllose, einem Wellenfieber mit regelmäßigen Fieberanfällen Unfruchtbarkeit und Aborten

- der Paratuberkulose des Rindes, die sich in chronischem Durchfall äußert

- respiratorischen Infektionen durch Mykoplasmen bei Huln und Pute

Chancen bietet die Diagnostik auch bei Erbkrankheiten und Krankheiten mit genetischer Komponente: Genannt sei die Identifikation des Gens für die Streßanfälligkeit von Schweinen.

Durch die Gendiagnostik können also unauffällige Träger von krankheitsverursachenden Erbanlagen frühzeitig identifiziert und von der Zucht ausgeschlossen werden. 